\title{
Por entre as Fissuras do Modelo Republicano Francês: Análise Fúlmica de O Ódio (1995) de Mathieu Kassovitz
}

Francisco Toledo Dayrell de Lima

\section{Introdução Contextual e Atualidade do Tema}

\author{
A França é uma República indivisível, \\ laica, democrática e social. Ela assegura \\ a igualdade perante a lei a todos os \\ seus cidadãos sem distinção de origem, \\ de raça ou de religião. \\ (Artigo 2, Constituição de 1958)
}

No dia 6 de Abril de I993, a polícia no $18^{\text {ime }}$ arrondissement de Paris abordou três jovens, dois deles menores de idade, que estavam supostamente roubando cigarros. Há uma grande população imigrante nesta área e os habitantes reclamam dos incessantes controles de identidade e policiamento bruto. Um dos jovens abordados tinha I7 anos e se chamava Makomé M'Bowole, nascido no ex-Zaire. Ele foi levado à delegacia para conversar com o investigador de polícia. Após duas horas, ele foi posto em custódia. 
Por entre as Fissuras do Modelo Republicano Francês:Análise Fílmica ...

O Procurador exigiu a soltura dos jovens envolvidos. Os pais de M'Bowole não conseguiram ser encontrados. O oficial continuou o interrogatório, atirou e matou o menor. Segundo as testemunhas, o menor estava xingando o oficial. Este se irritou e colocou sua arma na têmpora do menino, disparando por acidente. "Eu só queria assustá-lo": foi o que o oficial disse em sua defesa. ${ }^{1}$

Esse episódio resultou numa série de violentos distúrbios, que o filme O Ódio (I995), de Mathieu Kassovitz usa como ponto de partida para delinear a realidade social da França contemporânea. A semelhança com o ocorrido doze anos depois é assombrosa - quando uma perseguição policial, culminando na morte de dois jovens eletrocutados ao se esconder num transformador de energia de alta tensão, desencadeou dias de revoltas e depredações públicas em outubro e novembro de 2005. Não parece ser um fato isolado e desviante, mas algo revelador do "malestar profundo" ${ }^{2}$ da sociedade francesa que o próprio presidente da França, Jacques Chirac, admitiu existir no seu comunicado oficial televisionado ao país. De fato, o país vem sendo palco do aumento do desemprego estrutural que atinge majoritariamente as populações das banlieues e do recrudescimento da repressão policial e de inúmeras discriminações - particularmente ligadas à imigração.

Trata-se de um fosso conceitual e real entre os franceses "genuínos" e os franceses estrangeiros (por exemplo, filhos de imigrantes). Mas afinal, quem são os estrangeiros? Os recém-imigrados, que não possuem cidadania francesa, ou os franceses considerados menos franceses, por causa de suas origens étnicas? Essa confusão pode ser nula nos rigores formais da lei, mas a experiência cotidiana das discriminações revela que o modelo republicano francês e seu humanismo universalista estão fraturados...

$\mathrm{O}$ ano de I968 é sempre evocado como marco de rupturas. A França vivia o auge de "trinta anos gloriosos" de prosperidade econômica. A tônica de I968 era a ruptura com padrões comportamentais atrasados, que não mais condiziam com os novos tempos. A pílula anticoncepcional trazia as mulheres para a arena da participação na sociedade e urdia a liberdade sexual. A Guerra do Vietnã escrachava a estupidez das agressões militares e do uso de jovens alistados como buchas de canhão. Nos EUA, os negros se levantavam contra a ancestral discriminação que sofriam. As instituições educacionais já não condiziam com a expectativa dos jovens universitários. Era uma reação contra um estado de coisas. Havia, em toda parte, uma espécie de denomi-

I Episódio tirado do relatório de 1994 da Anistia Internacional sobre os abusos de direitos humanos cometidos pela polícia francesa, disponível no site http://www.jura.uni-sb.de/france/Law-France/ai.html.

2 Dossiê "Émeutes en France", disponível no site www.afrik.com (cf. bibliografia). 
nador comum nas diferentes manifestações: a recusa ao modo de vida e às regras do jogo que o capitalismo impunha. Por trás das manifestações, havia um sonho, uma utopia. Foram momentos de explosão coletiva em busca de saídas coletivas.

A atual rebelião dos jovens europeus é diferente. É uma explosão de raiva, um extravasar de sentimentos contidos. Estão fartos de serem estrangeiros em sua própria terra. Filhos de imigrantes, mas nascidos na Europa, sofrem a dura exclusão de serem muçulmanos, negros, mestiços. Estão fora do mercado de trabalho, como sempre estiveram fora da aceitação como cidadãos de fato. Diferentemente de seus pais, que migraram para a Europa quando havia trabalho em abundância e faltava mão-de-obra, os que agora incendeiam carros são vítimas de uma crise de identidade: têm menos vínculos culturais com a terra dos pais e não são aceitos no país onde nasceram e se criaram. Desterrados, são identificados como população-problema e vítimas de todos os estigmas negativos. A atual rebelião juvenil européia é mais do que apenas expressão de vandalismo. É ao mesmo tempo um pedido de socorro, de maior visibilidade e uma demonstração de recusa. Recusa à fatalidade da exclusão social, que os condena à condição de desnecessários e indesejáveis. Mas não parece estar alicerçada em um projeto de utopia. Diferentemente de I968, os que promovem a revolta de agora não querem mudar o mundo; apenas pedem para entrar nele...

Tendo em vista esta introdução contextual, pensamos em fazer uma análise de $O$ Ódio focando a maneira como as diversas violências se evidenciam no filme. No entanto, resultaria num ensaio redundante, pois a violência permeia o filme todo e está presente nas falas dos atores, nas agressões que sofrem, na arquitetura da cidade etc... Na verdade, estaremos sempre falando de violência, mas preferimos focar tão somente na realidade social e nos aspectos da cultura francesa contemporânea a que estão sujeitos os jovens das banlieues. A confusão entre realidade social e realidade fílmica é proposital. Nos ateremos portanto em como esta juventude e o meio que a cerca são filmicamente construídos; e em como esse processo de ida e vinda entre realidade e representação fílmica pode nos iluminar mais sobre os fenômenos de marginalização e violência nas sociedades contemporâneas. No presente caso, focamos a França; mas alguns pontos podem ser de interesse para o contexto brasileiro.

\section{Análise Fílmica}

O Ódio, escrito e dirigido por Kassovitz, é um filme que ostensivamente retrata a brutalidade policial contra os jovens beurs (termo nativo que designa os árabes nascidos na França) e outros imigrantes de origem africana. O filme, num estilo 
documental em preto e branco, usa ferramentas do realismo social para narrar 24 horas da vida de três banlieusards: Vinz, um judeu branco; Saïd, um beur; e Hubert, um negro. A narrativa é estabelecida a partir da revolta incitada por um incidente de abuso policial que deixa em coma Abdel, um amigo deles, logo após apanhar sob custódia da polícia. Outro fato importante é que Vinz encontra uma arma que um policial perdeu durante as manifestações e isto acarreta modificações no comportamento dele. A escolha da caracterização também é interessante porque subverte certos pré-conceitos que geralmente temos das diversas etnias representadas: Vinz, o invocado metido a gangster; Saïd, o ingênuo; e Hubert, o negro boxeador, íntegro e cheio da verdade, que ajuda a família com as despesas traficando haxixe. A própria cor do trio parece servir para tecer uma fábula social: um trio black, blanc, beur (numa ironia ácida com o bleu, blanc, rouge da bandeira francesa).

Com efeito, o filme incessantemente faz referências à realidade sociológica a que se propõe fazer uma ficção: Abdel é Makomé M'Bokole no filme e o enredo acontece num projeto habitacional fictício chamado Les Muguets; mas que alude a Les Minguettes, um projeto similar de Lyon, de onde nasceu o movimento Beur em I983, quando imigrantes de origem norte-africana das cités marcharam até o gabinete do presidente Mitterand gritando palavras de ordem por igualdade e fim do racismo ${ }^{3}$.

O que fica patente é que o filme confunde em si mesmo ficção e realidade social: é um filme que fala a si mesmo e à sua época sobre a sociedade que retrata; e toma emprestado elementos da realidade para construir uma narrativa e estética propriamente cinematográficas. Trata-se de uma espécie de antimito ou de fábula social em que realidade sociológica e texto experimentam uma certa contigüidade. Isto, por sua vez, deve ser relativizado, pois o filme também não é a representação transparente da realidade. Tal leitura "naturalizada" faz tanto mais parte da estratégia narrativa do próprio realismo social, que fomenta a confusão entre ficção e documentário e entre filme e realidade. O texto docu-ficcional enquanto produto cultural se mistura à realidade social a partir da qual foi construído e seu potencial analítico é, numa primeira leitura, posto de lado e submetido à narrativa fílmica. Três aspectos da cultura francesa contemporânea estão cristalizados em O Ódio:

- pós-colonialismo, caracterizado pela emergência de novas formas culturais em que há influência dos antigos colonizados na cultura do poder colonial;

- o abandono estrutural da juventude e conseqüente emergência de uma distinta identidade marginal separada do Centro (entendido em termos sócio-culturais);

3 Ver link na bibliografia (I988). 
- e a globalização (ou americanização), mais evidente no influxo de mercadorias, palavras, expressões americanas e nas referências culturais que de alguma maneira dão lugar a uma espécie de sincretismo cultural.

Esses desenvolvimentos históricos relativamente recentes formam o pano de fundo do filme e estão refletidos nas locações, na narrativa, na caracterização dos personagens, no diálogo, na linguagem cinematográfica propriamente dita, na trilha sonora e no estilo do filme. Vejamos como.

A cena de abertura mostra um beur de uns vinte anos, parado no meio da cité e, na frente dele, o horizonte está todo barrado por policiais da tropa de choque. O jovem vocifera: "Vocês só são uns assassinos. Vocês atiram... é fácil assim! Nós não temos armas, apenas temos pedras!". Já nos primeiros segundos do filme, uma oposição visual entre policiais e jovens é instaurada, reforçada pelo apelo dramático do rapaz. Numa primeira leitura, a retórica de Kassovitz parece clara: a polícia e a juventude formam uma oposição estrutural que irá encontrar seu desfecho na tragédia. Não obstante, o filme não descamba meramente num discurso inflamado contra a polícia, nem se atém inteiramente nesta oposição simplista. Pelo contrário, o filme parece mostrar uma diversidade de possíveis relações existentes nas banlieues, não somente entre a juventude e a polícia, mas entre pais e filhos, entre conhecidos e entre amigos; todos aqueles envolvidos cuja posição estrutural, cumplicidade e esforços em resistir contribuem para uma certa guetificação. Ademais, a primeira cena também já coloca um certo tom documental do filme com uma imagem granulada que reforça a crueza do material fílmico e a sensação de que o material é real, inédito e bruto (no sentido de não ter passado por nenhuma modificação estética e de ter sido captado precária e perigosamente).

$\mathrm{Na}$ segunda seqüência, uma imagem de satélite do globo terrestre é acompanhada por uma narração em off, que é repetida duas vezes no filme (com uma pequena, porém importante variação na última repetição) e que ajuda a enquadrar a narrativa como um todo: "É a história de um homem que cai de um edifício de cinqüenta andares. A cada andar, à medida que cai, ele se repete para se tranqüilizar: até agora, tá tudo bem, até agora, tá tudo bem, até agora, tá tudo bem... Mas o importante não é a queda, é a aterrissagem".

Esta espécie de anedota cria um paralelo entre a queda do indivíduo e o fracasso da sociedade. A continuação da cena, mostrando um coquetel molotov se chocando com o planeta Terra, estende a metáfora além: o que está de fato em jogo é o status da civilização e o bem-estar do mundo. Afinal, a pauperização trata-se de um fenômeno recorrente no mundo todo; e mais especificamente, trata-se da pauperização da juventude e da perda de expec- 
Por entre as Fissuras do Modelo Republicano Francês:Análise Fílmica ...

tativas desta. A retórica da cena sugere que o futuro da sociedade francesa depende das conseqüências da luta de alguns jovens num projeto habitacional parisiense.

Outros exemplos desta retórica são evidentes. Há uma cena de O Ódio que mostra bem a existência desses dois mundos segregados. Quando estão num metrô de Paris, Hubert examina um cartaz publicitário que diz: "o mundo é vosso". Ele fecha os olhos como que para segurar o choro enquanto um barulho agudo ensurdecedor agoniza a cena. Algumas cenas depois, um deles "corrige" o cartaz, trocando por "o mundo é nosso". Das duas uma, ou o mundo é dos jovens e a fórmula "o mundo é nosso" se assemelha ao brasileiro "é nóis na fita" - como uma espécie de possessão e subversão, pelo grafitti, da representação hegemônica do mundo; ou trata-se de uma sacada de humor negro em que é reiterada a dominação que o indivíduo das banlieues sente, mas para tão somente desbancar uma hipocrisia barata da propaganda oficial: "não vem com essa piedade, a gente sabe que o mundo é de vocês". Em ambos os casos, a campanha oficial do governo para dar estímulo aos jovens é posta em contraste com o desespero da juventude. Desespero e ódio por uma sociedade da qual quer fazer parte, mas que a barra na porta de entrada, ainda que constantemente a convide para dentro. Nesse sentido, a cena inicial do coquetel molotov explodindo a Terra se entenderia como a explosão da representação ideológica do mundo (e da publicidade a serviço desta).

Outra maneira que o diretor encontra para reforçar visualmente o contraste entre Centro e banlieues se encontra nas tomadas do deserto suburbano. Em diversas tomadas, frisa-se um ângulo aberto, amplo e distanciado, que mostra grandes espaços com pouca gente e mostram o vazio no qual os indivíduos moram... Isto revela também o caráter opressor da arquitetura do concreto, imponente por cima dos banlieuesards. Temos então duas Paris: conjuntos habitacionais feios cobertos de piches com xingamentos e mensagens de ódio em contraste com o apartamento luxuoso de Astérix; estacionamentos vazios e espaços abertos em contraste com bulevares elegantes cheios de vida.

Há várias cenas em que o deserto é conjugado com o tédio e a desolação dos indivíduos, consumo de drogas, pouca conversa e historinhas idiossincráticas. Há imagens que mostram o trio sem dizer nenhuma palavra, cabeça baixa, enquanto atrás há um grafitti dizendo: "O futuro somos nós. O futuro na cidade somos nós". Outro elemento cinematográfico que Kassovitz utiliza é a cartela de texto em fundo preto de um relógio. Esse relógio aparece diversas vezes no filme e marca horários aleatórios da trajetória do trio. Temos o sentimento de estar acompanhando em tempo real os eventos. Isto reforça o realismo docu- 
mental do filme. Mas também dá mais ênfase ao ócio e ao tédio dos jovens das cités. E vai criando tensão rumo à tragédia do final.

Logo após a cena do trem, o trio chega a Paris e fica parado num viaduto em cima do tráfego da cidade. Por um jogo de câmera e zoom acelerado, temos a sensação de estarmos nos aproximando dos personagens ao mesmo tempo em que as imagens da cidade caótica atrás vão chegando. A sensação que temos é que os personagens estão sendo comprimidos por esses dois zooms. Eles estão inertes e parecem estar sendo engolidos pela cidade. Os jovens são dramaticamente colocados em relevo em oposição à indiferença do tráfego da cidade e de seus edifícios logo atrás deles. Assim, além de já terem sido colocados em oposição à polícia, aqui eles estão em direta contraposição com as representações oficiais das cidades francesas. Trata-se da oposição entre França invisível e França visível.

Em outro momento, um dos protagonistas diz em contraste com a Torre Eiffel no horizonte distante: "é como nós na cité, por enquanto tá tudo bem". Essa imagem relembra a anedota inicial da queda do indivíduo e funciona como contraponto visual, opondo uma representação oficial da cultura francesa ao indivíduo marginalizado. Quando Saïd estala os dedos, a luz da Torre Eiffel apaga; entretanto, isso só acontece quando ele está de costas para a Torre. A brincadeira cinematográfica se torna em parte uma piada sobre o protagonista em si. Se a autoridade da cultura oficial é (simbolicamente) subvertida, pelo estalo dos dedos, o indivíduo não está consciente de sua "agência" ou de sua presença na cultura oficial. Ao justapor os símbolos da cultura francesa e a juventude das banlieues, essas espécies de "piadas visuais" são sugestivas da complexa relação entre indivíduos e as estruturas sociais. A cultura se mostra fixa e imodificável para o indivíduo marginalizado, mas paradoxalcamente, tal posição acaba sendo um lugar privilegiado de resistência e de emergência de novas formas de cultura.

Logo após o mundo explodir com o coquetel molotov, começam os créditos iniciais. Imagens das revoltas que aconteceram logo após a morte de Makomé M’Bokole são acompanhadas pela música Burning and looting de Bob Marley. Não são reconstituições ficcionais, mas material de televisão e de cinegrafistas amadores que foram incorporados ao filme. Aqui, são usadas como se fossem as manifestações decorrentes do espancamento de Abdel, para reforçar a plausibilidade do relato ficcional e já colocar a narrativa, de início, numa chave de tensão. Carro incendiado. Policiais preparando carros com grades para confronto com manifestantes. Glose nos equipamentos de repressão: cassetete, capacete com visor, escudos de proteção. Cenas de confronto direto: manifestantes pulando e atacando coisas, policial jogando bomba de efeito moral, saqueadores de loja, cenas de agressão, manifestante sendo arrastado pelo chão. Policiais à paisana batendo em manifestantes e levando-os para dentro do cerco policial. 
Por entre as Fissuras do Modelo Republicano Francês:Análise Fílmica ...

Marca de tiro (balas de borracha são só supostamente usadas pela tropa de choque). Cartazes com os dizeres: "Não se esqueçam que a polícia mata. Mesmo crime, mesmos cuzões"; e por fim, a clara referência ao assassinato de Makomé, um grafitti que diz: "Que justiça seja feita por Mako".

Cabe ressaltar o uso da trilha sonora nessa seqüência. No momento que a música diz "wearing uniforms ofbrutality", a imagem fixa na mão de um policial segurando um cassetete. Ou quando pessoas começam a saquear as lojas, começa o refrão: "That's why we gonna be burning and looting". Muitas das faces dos policiais estão borradas e isso também coincide com a letra da música: "could not recognize the faces all over me". Ademais, esses borrões podem ser interpretados de duas maneiras: para preservar a identidade dos filmados (e assim assegurar sua posterior segurança) e para criar sócio-tipos de maneira que a pessoa perde sua individualidade em detrimento da força que ela confere ao argumento sociológico e mais geral do filme. Novamente, temos a oposição entre policiais e jovens.

Justo após os créditos iniciais, o realizador encena uma matéria de telejornal e insere as imagens das manifestações que acabamos de ver na ficção. Isso permite que a ficção adquira uma certa realidade, corroborada pela realidade midiática. Ele utiliza a passagem jornalística para fazer a passagem de tomadas reais para tomadas encenadas. Aqui, aquilo que se configura como uma crítica ao discurso jornalístico, aparece também como o recurso que confere mais confusão entre realidade e ficção. Em outro trecho do filme, esta crítica à mídia fica evidente quando uma jornalista e os três jovens discutem: "Vocês estão sabendo da arma do policial que circula na cité? E vocês mesmos, o que vocês fariam com ela?" pergunta a jornalista. "A gente parece com trombadinhas?" diz Saïd; "Porque vocês não descem do carro?" acrescenta Hubert; e por fim, Vinz começa a insultá-la: "Vocês têm que trabalhar? Tipo o quê? Meter o bedelho, procurar algo bem sensacional pra fazer um furo? (...) Sai do meu bairro antes que a gente queime vocês, seus bostas. Nós não estamos em Thoiry!”. Thoiry é uma espécie de Simba Safari francês, um zoológico que se cruza de carro. Essa cena é uma contundente crítica ao medo do Centro de entrar na cité, a não ser pelo olhar sociocêntrico e sensacionalista de alguns corajosos jornalistas. É também uma crítica ao exotismo que as banlieues parecem exercer ao Centro, que provém tanto mais da ignorância e do desconhecimento da vida real destas localidades pelo Centro.

No entanto, em termos de estilo cinematográfico, a linguagem usada no filme se assemelha à linguagem dos clipes da MTV e da televisão em geral; e utiliza isso para brincar, criticar e atrair a atenção daqueles que estão acostumados com a linguagem televisiva. E brinca também com o tipo de visibilidade que normalmente é conferida às banlieues: uma visibilidade programada e bem delimitada, em detrimento de tantos outros aspectos mantidos na invisibilidade. 
Assim, ficamos ora com os estereótipos "positivos" de sitcoms e novelas francesas que mostram uma banlieue com cara de Centro; ora com estereótipos negativos, principalmente veiculados pelos telejornais, que sempre identificam as banlieues com as armas, as drogas e o gangsterismo.

Voltando à oposição entre policiais e jovens, convém salientar também que o filme tenta mostrar a polícia como complexa, composta por diferentes classes sociais, etnias, idades e personalidades. Além disso, precisamos fazer um parêntesis e distinguir as tropas de choque (CRS) e os policiais civis. O CRS é uma força paramilitar que o governo usa em situações de manutenção da ordem. Esta é a força policial que vemos nos créditos iniciais. O propósito da polícia civil, que é supostamente composta por membros da própria sociedade civil, é, em princípio, "servir e proteger" o povo. Esses policiais diferem enormemente dos oficiais do CRS, que são chamados apenas em situações emergenciais. Os policiais civis são aqueles que lidam com a população cotidianamente e o filme tenta abordar essa dimensão, sem excluir as brutalidades. São estes policiais civis que invadem o churrasquinho no telhado e são expulsos pelos banlieusards. Nessa cena especificamente, já se vê a heterogeneidade da força policial. O oficial mais velho, um francês clássico que apela para valores universais (respeito pela autoridade e pela cultura francesa) ordenando que desçam "dans la joie et la bonne humeur" (num tom bem cínico e hipócrita). Mas também os dois outros oficiais, que são claramente beurs, que se vestem de maneira casual (um deles até veste uma jaqueta parecida com as vestimentas dos jovens) e que querem que os jovens se identifiquem com eles (eles até conhecem os nomes de alguns jovens).

Em outra cena, o trio vai visitar Abdel no hospital mas é barrado por um jovem e inexperiente policial. Ele diz que não quer problemas e só está fazendo seu trabalho. Ele não é de maneira alguma agressivo. Pelo contrário, ele tem dificuldade em afirmar sua autoridade. Alguns segundos depois, o tumulto chama a atenção de um policial negro, esse sim autoritário e agressivo, que prende Saïd, acusando-o de ser o chefe dos desordeiros. O que fica patente aqui é a heterogeneidade de comportamentos e origens étnicas dos policiais. Embora o filme certamente se ancore na oposição estrutural entre jovens e policiais, o filme também relativiza esta visão em cenas como estas.

Um outro exemplo (estrutural) nesse sentido é a distinção lingüística e formal que os franceses fazem ao se dirigir a uma pessoa. Isto é explicitado numa outra cena em que Saïd pede informações a um policial na rua. $\mathrm{Na}$ maioria dos casos, é tacitamente obrigatório usar o vous, ou seja o nosso vós, para falar com estranhos e pessoas com as quais não se tem intimidade ou que detêm alguma fonte de autoridade (professores, policiais e até os próprios pais). O tu é reservado para amigos íntimos, amantes, ou quando, conscien- 
Por entre as Fissuras do Modelo Republicano Francês:Análise Fílmica ...

te ou inconscientemente, se quer rebaixar alguém. Desta maneira, uma das grandes reclamações dos jovens de periferia é que a sociedade exige deles um tratamento diferenciado que não os contempla: eles são constantemente tratados de tu quando devem se referir a todos por vous. Nesta cena, Saïd fica surpreso de ver um policial lhe dirigir a palavra por vous: "Porra, eles são educados, os 'gambé' aqui. Dizem vous e tudo".

Apesar de certas cenas mais relativizantes e, de certo modo, condescendentes, não podemos perder o tom mais geral do filme: a crescente tensão (que já começa em alta nas cenas iniciais de manifestação), constantemente reiterada pelas falas agressivas dos personagens e pelo tique-taque irritante do relógio, e muito menos as cenas cruas e nuas de violência racial (perseguição dos skinheads) e abuso policial. Não é à toa que uma das últimas cenas do filme é uma das mais fortes e mostra Hubert e Saïd sob custódia policial sendo amarrados, insultados racialmente e torturados. Portanto, o filme acaba na mais extrema polarização. Assim, o filme pode ser visto como uma espécie de crítica das categorias e conceitos que geralmente são usados para dar crédito à ideologias racistas. Ao menos seria justo dizer que as caracterizações dos personagens ajudam o filme a funcionar como ficção e dar ao diálogo uma profundidade: "A maioria dos policiais na rua não estão aí para bater em vocês; eles estão aí para proteger vocês" diz o oficial beur; "Pois é, mas quem vai nos proteger de vocês?" responde Hubert.

Mas o filme não parece focar sua atenção principalmente no racismo em si. Quando mais, parece lidar com as condições sociais e políticas, as forças repressivas e as limitações econômicas às quais os imigrantes estão sujeitos em geral. Mais do que isso, parece lidar com uma certa ideologia do outro, uma alteridade que é corolária do processo de guetificação. Além de serem atingidas por condições sociológicas que contribuem para a estagnação e o isolamento social, as banlieues se tornaram representativas de uma realidade cultural distinta, com sua própria linguagem, seu próprio sistema de troca e economia, e sua própria identidade. Trata-se de uma espécie de subcultura, que não destoa por completo da cultura oficial e muito menos da cultura capitalista (cultura do consumo).

Subcultura essa que se evidencia nas vestimentas, na música hip-hop, no grafitti, na cultura das drogas e principalmente no uso da linguagem. Aqui cresce a distância entre a representação oficial da cultura francesa e a realidade social assim como os jovens das banlieues a significam. A linguagem falada no filme é identificável por qualquer francófono como a linguagem específica da juventude, e em particular, da juventude da periferia. O verlan (que é l'envers ao contrário), uma forma de código lingüístico em que a ordem silábica das palavras é invertida, embora já tenha existido antes do desenvolvimento das banlieues, 
reemergiu como um marcador de identidade para a juventude contemporânea. Não só ele distingue as gerações mais jovens dos adultos, como diferencia o suburbano do urbano. É muito comum a criação de termos em verlan. No filme, vários desses termos são repetidos inúmeras vezes e marcam uma distinção geral entre moradores dos centros urbanos e aqueles das margens - muito embora exista também na França a incorporação desse linguajar pela juventude do centro como modismo ou marcador de identidade "jovem”. Assim, temos o teushi (shit - haxixe), o québri (briquet - isqueiro), keuf (flic - policial), relou (lourd - pé no saco), meuf (femme - mulher), e assim por diante...

A cena em que Vinz, Hubert e Saïd acabam entrando num vernissage numa galeria de arte mostra claramente o contraste entre culturas distintas e falares distintos. De início, quando o trio entra na galeria, eles não são colocados à parte dos outros de nenhuma maneira, a não ser pela roupa, mas eles são temporariamente aceitos naquele grupo. São-lhes oferecidos comes e bebes e nenhuma forma de discriminação acontece. Antes de o conflito começar, Saïd critica a exposição: "que coisa feia!". Aqui, temos também colocada a oposição entre arte de rua e arte dita de "alta cultura", já que Saïd representa o gosto pelo grafitti. Em seguida, o conflito irrompe quando Saïd se interessa por uma mestiça e pede a Hubert para que ele arranje sua aproximação na moça. Ela gosta do convite e os dois se apresentam. Nesse momento, o modo de expressão de Saïd se confronta com padrões de comportamento com os quais ele está aparentemente desfamiliarizado: "Você é gostosa", ele diz. Conforme o conflito aumenta e a atenção é voltada ao trio, uma das meninas diz: "A gente tá tranqüilo em falar com vocês, mas vocês já ficam agressivos! Como é que vocês querem que nós respeitemos vocês?”. Não é só que Saïd esteja sendo grosseiro (os protocolos lingüísticos são de extrema importância para os franceses), mas ele está inserido numa subjetividade que presume um certo entendimento lingüístico comum e esse entendimento está em completo descompasso com as normas do centro. E nesse sentido, a grosseria de Saïd adquire uma certa ingenuidade e uma clara ignorância dos padrões comportamentais que ele deveria observar: sua intenção não foi ser agressivo.

Outro ponto crucial da subcultura das banlieues é um certo sincretismo cultural que provém da incorporação de elementos culturais oriundos dos Estados Unidos. Isso fica evidente na cena do break e nos vários grafittis que vemos no filme. A título de exemplo, há uma cena em que Saïd fica em frente a um furgão do CRS. Vemos os rostos dos policiais en passant, mas podemos ver que se tratam de diversas etnias. Saïd faz um tag (grafitti) no furgão: "Saïd fode a polícia". Aqui duas coisas ficam evidentes: a mensagem que o tag explicitamente coloca de ódio e antagonismo frente às forças da ordem, e o tag enquanto suporte de identida- 
de. A câmera fecha no tag de Saïd. Um detalhe quase passa desapercebido, mas logo abaixo há um a dentro de um círculo, como no símbolo de copyright. De fato, isso corrobora que aquilo se trata da marca registrada de Saïd e de uma autêntica cultura jovem e suburbana que ele representa.

Em outro momento, o embate entre cultura francesa e cultura globalizada (um tanto quanto americanizada) fica mais evidente: a remixagem de Assassins de la police (que já é uma versão francesa de The sounds of police) com Edith Piaf cantando "Je ne regrette rien", enquanto a câmera sobrevoa os telhados da cité. O próprio uso da música Burning and looting de Bob Marley é significativo, já que Marley foi particularmente ativo na luta pelo fortalecimento cultural das identidades pós-coloniais.

Nas banlieues, a figura do rapper gangster desempenha um papel simbólico de ícone na identidade popular pós-colonial. Essa identificação pode estar enraizada na grande dificuldade que os jovens têm de encontrar uma imagem de si mesmos nos produtos culturais oficialmente franceses. Ademais, a própria igualdade frente à lei é comprometida pelo sistema judiciário e político e assim os jovens não têm como se sentir iguais ao modelo que os oprime. Frente a esta não-identificação com a identidade francesa, eles procuram outras referências culturais. Sempre houve uma tendência em olhar os Estados Unidos como um modelo e, mesmo que não seja um modelo conscientemente adotado, sua parte dominante no que compõe a cultura globalizada é indiscutível. No que tange nossa discussão, são os ideais de melting pot, a recente história de luta e protesto pelas liberdades civis dos negros e a atração do estilo e da retórica do hip-hop que promove imagens de orgulho negro e inconformidade com as injustiças sociais. Essas projeções se deshistoricizam nos fluxos interculturais que as fazem tomar forma em outros locais. Ao invés da imagem de uma sociedade americana em que a desigualdade racial persiste, as imagens do protesto social e da identidade marginal são as que ficam, independentemente do significado cultural de origem.

Ironicamente, no filme, quem adota essa postura de gangster é Vinz, o judeu francês; enquanto Hubert, o negro, é super crítico quanto a isso. Isto novamente expressa um nível de complexidade que nega uma representação monolítica das banlieues e da juventude. Nesse sentido, Vinz e sua identificação com o gangsterismo são exemplos interessantes de inversões simbólicas que podem acontecer quando produtos culturais e símbolos são difundidos por meio do sistema mundial-capitalista de troca. Uma vez separado de seu contexto, o produto está disponível para ser apropriado pelos mais variados atores, como os jovens das banlieues, que resignificam este mesmo dentro do quadro social em que vivem. Então, é criada uma certa autenticidade para esta nova identidade imaginada: o gangster-banlieue ou algo assim. Isto também se 
vê na escolha das roupas, os macacões Adidas, Nike e Tachini, que são claras alusões a cultura hip-hop e do break.

Em outra parte do filme, temos Vinz olhando para si mesmo no espelho, fingindo sacar sua arma: "Cê tá falando comigo, porra?" ele repete, "Cî tá falando comigo?". Aqui a alusão ao personagem Travis Bickle em Taxidriver, de Martin Scorcese, é chocante. Aliás, Kassovitz trava "diálogos" com Hollywood em diversos momentos: o clima de tensão similar a Do the right thing, de Spike Lee; "Le monde est à vous" lembra o "The world isyours", de Scarface; ou ainda, a cena final, em que não vemos quem atira em quem, podia ser a cena final de um filme de John Woo...

Mas quem é esse Outro imaginário com quem Vinz grita? Ele poderia estar gritando consigo mesmo, ou gritando com a França, ou até mesmo com a cultura globalizada. As três opções detêm suas plausibilidades, mas o forte nesta cena é mostrar o ódio e a disjunção entre o eu e a imagem de si para os outros.

\section{Catarse Social e Conclusão}

Ghegamos à cena final de O Ódio, em que Hubert se confronta com um policial francês. Um pouco antes, um mural de Baudelaire paira por cima do trio, servindo como um contraponto irônico à cena do confronto final, novamente opondo um símbolo público da dita "alta cultura" (que carrega os ideais da civilização francesa) à realidade social das banlieues assim representada pelo três jovens. Vinz finalmente entrega a arma a Hubert, que durante o filme inteiro tinha tentado convencer o amigo da futilidade da violência e da inautenticidade de sua postura gangster. Temos aqui um falso final: o conflito do filme parece ter chegado a uma resolução. Mas assim que eles começam a andar, a polícia chega e começa a mexer com Vinz e Saïd. Hubert fica à distância, apenas observando um dos oficiais (um beur) encostar uma arma na cabeça de Vinz. A arma dispara. Hubert se aproxima como que num transe. Ele aponta a arma para o oficial. O policial aponta a sua para Hubert. A tela fica preta; ouve-se um tiro. Não se sabe quem deu o tiro... É nesse momento que a anedota inicial da queda retorna. Kassovitz introduz a moral do filme, mudando ligeiramente a narração de entrada: "É a história de uma sociedade que cai de um edifício de cinqüenta andares". As quedas do indivíduo e da sociedade estão intensamente atreladas...

Assim, assiste-se a uma guerra de dois mundos onde cada qual reage em função da imagem que faz do outro. Os policiais pensam que lidam somente com delinqüentes ou arruaceiros e agem unicamente na função de manter a ordem. Essa atitude, ao mesmo tempo defensiva e ofensiva, acaba por segregar mais esses dois mundos: a polícia não tem uma função educadora, mas repressora. Do outro lado, 
os jovens das banlieues, em sua grande maioria, acham que a polícia só existe para importuná-los, exigir papéis de identidade ou abordá-los. Dessa relação tensa, somente resta a incomunicabilidade ou a violência como derradeira comunicação.

Essa sensação de que, em qualquer momento, tudo vai ruir e debandar numa guerra civil, é constante nos jovens das banlieues: eles sempre falam que não agüentam mais as provocações policiais e uma hora ou outra a paciência se esgotará, assim como se esgotou nos distúrbios ocorridos em outubro e novembro de 2005.

\section{Imagens Anexadas}

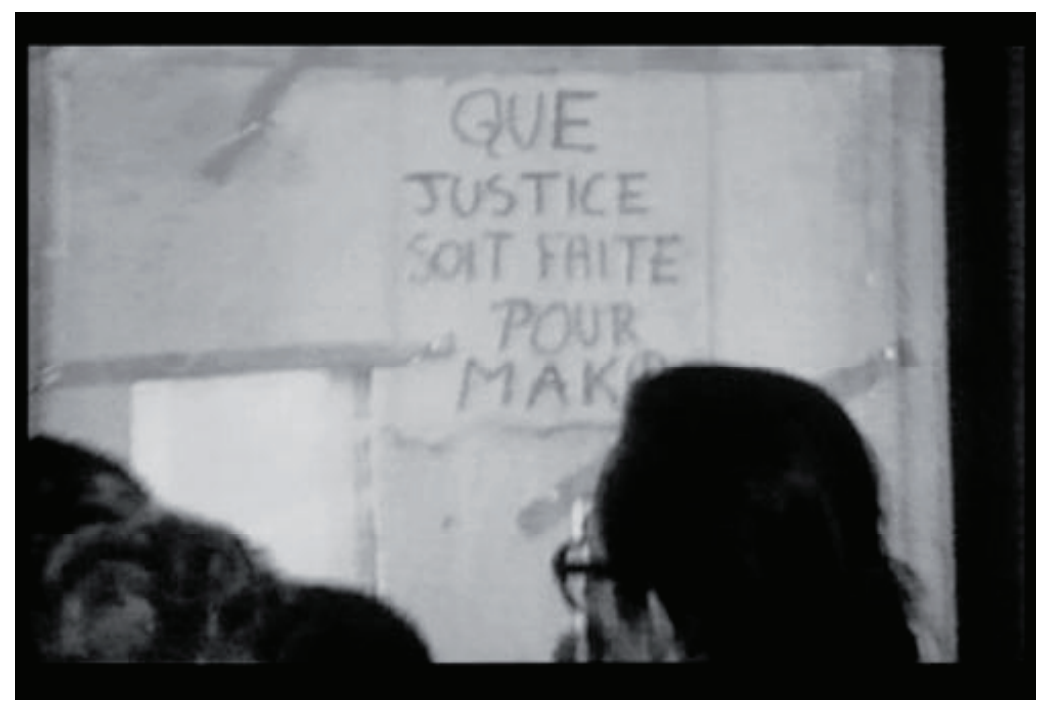

Referência ao assassinato de Makomé M'Bokole

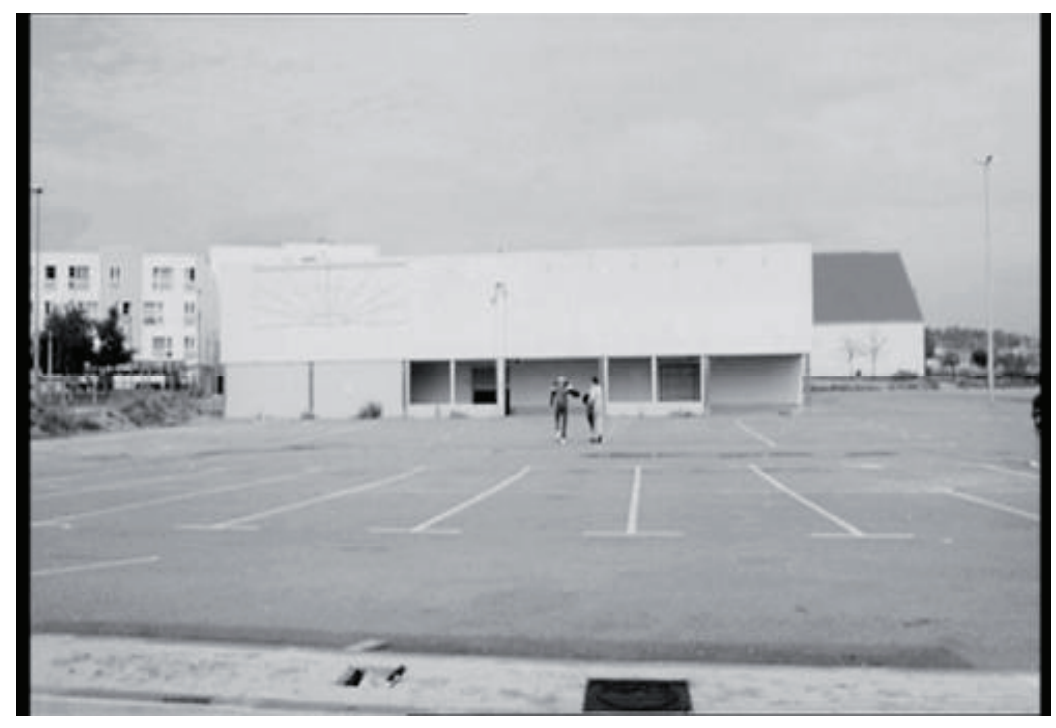

O deserto suburbano e a vastidão desoladora 


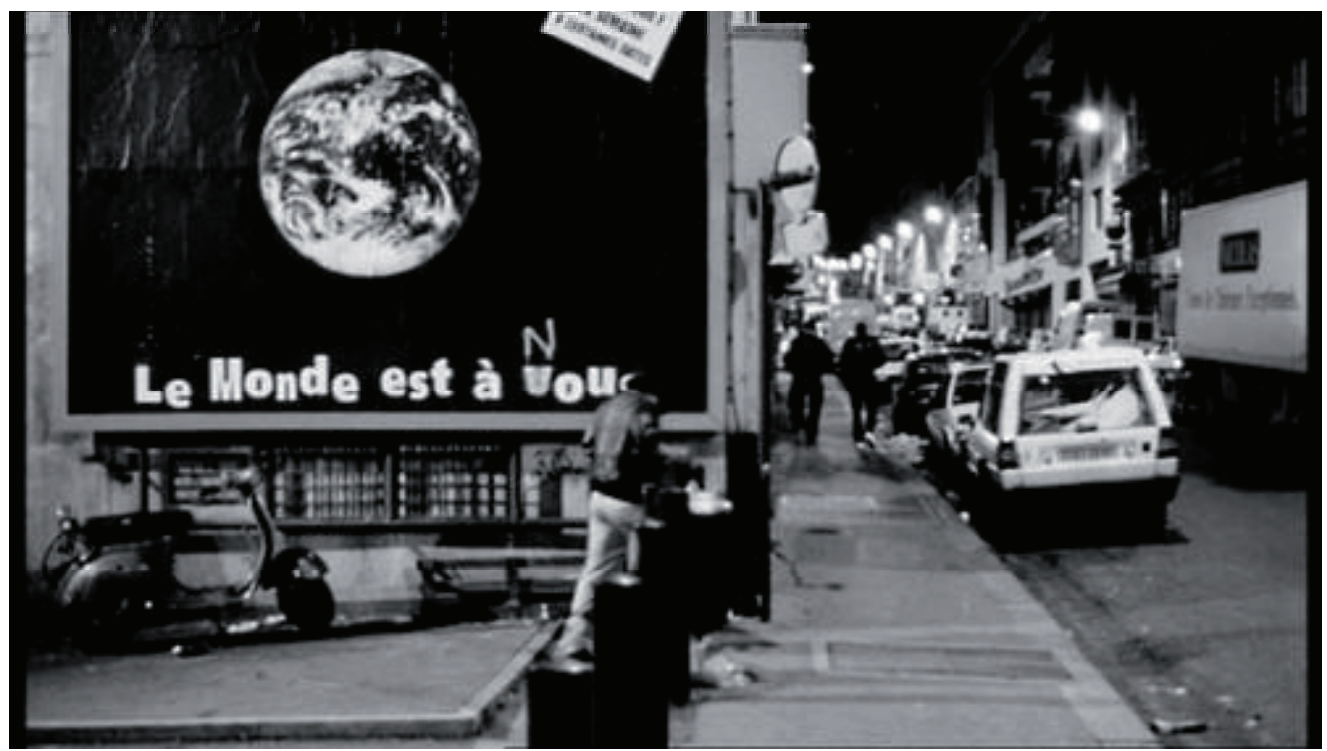

A propaganda oficial do governo e a subversão pelo grafitti

\section{Bibliografia de Apoio}

Beaker, Howard. "Visual Sociology, Documentary Photography, and Photojournalism: It's (almost) All a Matter of Context". In: Prosser, John (ed): Image-based research. London: Falmer Press, I998.

Bourdieu, Pierre. Language \& symbolic power. Cambridge: Harvard University Press, I994.

Ganevaca, Massimo. Antropologia do cinema. São Paulo: Brasiliense, I99o.

GraWford, Peter Ian. "Film as discourse: the invention of anthropological realities". In: GRAWFORD \& TURTON: Film as ethnograpghy. Manchester e Nova Iorque: Manchester University Press, I995.

Sorlin, Pierre. Sociologia del cine - La apertura para la historia del mañana. México D.F.: Fondo de Cultura Económica, I985.

TAYLOR, Lucien (ed.). Visualizing theory. Nova Iorque: Routledge, I994.

WArnier, Jean-Pierre. La mondialisation de la culture. Paris: La Découverte, 2004 . 
Por entre as Fissuras do Modelo Republicano Francês:Análise Fílmica ...

Weakland, John H. Feature films as cultural documents. In: Hockings, Paul (ed.). Principles of visual anthropology. Nova Iorque: Mouton, I995 [I974].

\section{Artigos da Internet}

Dossier "Émeutes en France". afrik.com: online. Disponível em: http://www.afrik. com/dossier249. html. Acesso em: I março 2007.

LAROnde, Michel. La "Mouvance beure": émergence médiatique. French Review, V. 6I, N. 5 (Apr., I988), pp. 684-692. Disponível em http://links.jstor.org/ sici? sici=0 O16-111X\%28198804\%2961\%3A5\%3C684\%3AL\%22BEM\%3E2.0.CO\%3B 2-Y\&size $=L A R G E$. Acesso em : $\mathrm{I}^{\circ}$ março 2007.

Amnesty International. Rapport d'Amnesty International - Octobre 1994. Disponível em: 〈http://www.jura.uni-sb.de/france/Law-France/ai.html〉. Acesso em: I ${ }^{\circ}$ março 2007.

\section{Filmografia}

La Haine. Direção de Mathieu Kassovitz. Universal: I995. 96 min. DVD, Ntsc, son., P/B. Legendado. Port. (Lançado no Brasil em janeiro de 2007).

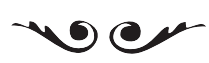

FRANGisco Toledo Dayrell de Lima é graduado em ciências sociais pela USP.

E-mail: pzykm@yahoo.com. 